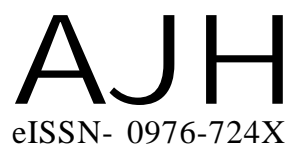

Received : 22.02.2014

Revised : 26.09.2014

Accepted : 12.10.2014
Author for correspondence :

\section{RAJA NAIK}

Horticultural Research Station,

Vijayrai, WEST GODAVARI (A.P.)

INDIA

Email : naik_raja2006@rediffmail.

com
THE ASIAN JOURNAL OF HORTICULTURE

Volume 9 | Issue 2 | Dec., 2014|315-318

Visit us -www.researchjournal.co.in

\title{
Influence of nitrogen and phosphorus on flowering of African marigold (Tagetes erecta L.) var. Cracker jack
}

\section{RAJA NAIK}

ABSTRACT : Marigold is one of the most important commercially exploited flower crops in India. A field experiment was conducted during 2000 to study the influence of nitrogen, phosphorus on flowering of African marigold. The results revealed that among four levels of nitrogen, highest level of nitrogen $\left(\mathrm{N}_{3}\right)$ took significantly minimum days to full flowering (50.66 days) and plants which received $\mathrm{N}_{2}$ recorded significantly higher number of flower heads per plant (28.42), size of the flower head (5.59 $\mathrm{cm})$, fresh weight of the flower heads per plant $(71.25 \mathrm{~g})$ and yield $(11.11 \mathrm{t} / \mathrm{ha})$. Among three levels of phosphorus, days to full flowering were earlier (51.41 days) in the treatment without phosphorus $\left(\mathrm{P}_{0}\right)$. However, number of flower heads per plant (28.30), size of flower head $(5.74 \mathrm{~cm})$, fresh weight of the flower heads per plant $(69.65 \mathrm{~g})$ and yield (10.80 t/ha) was higher in $\mathrm{P}_{2}$. In interaction of nitrogen and phosphorus, the combination of highest level of nitrogen without phosphorus $\left(\mathrm{N}_{3} \mathrm{P}_{0}\right)$ recorded early flowering (50.00 days). Number of flower heads per plant (31.83), fresh weight of the flower heads per plant $\left(75.13 \mathrm{~g}\right.$ ) and yield (11.65 t/ha) was higher in $\mathrm{N}_{3} \mathrm{P}_{2}$. Thus, the experiment proved that nitrogen application advanced flowering, while phosphorus application delayed flowering.

KEY WORDS : Marigold, Nitrogen, Phosphorus, Flowering

HOW TO CITE THIS ARTICLE : Naik, M. Raja (2014). Influence of nitrogen and phosphorus on flowering of African marigold (Tagetes erecta L.) var. Cracker jack. Asian J. Hort., 9(2) : 315-318. 